Bangladesh J. Plant Taxon. 25(2): 295-297, 2018 (December)

(C) 2018 Bangladesh Association of Plant Taxonomists

\title{
LECTOTYPIFICATION IN ARDISIA ALATA H.R. FLETCHER (PRIMULACEAE)
}

\author{
Wannachai Chatan ${ }^{1}$ and Wilawan Promprom \\ Department of Biology, Faculty of Science, Mahasarakham University, \\ Kantharawichai, Mahasarakham 44150, Thailand
}

Keywords: Ardisia alata; Myrsinaceae; Nomenclature; Thailand; Typification.

The genus Ardisia Swartz (Primulaceae) consists of about 400-500 species (Chen and Pipoly III, 1996) and it is pantropical, mainly tropical Amercas and Asia, a few in temperate Japan (Ståhl and Anderberg, 2004). Among these, Ardisia alata H.R. Fletcher is an endemic species found in Takuapa and Kapong districts under Phangnga Province of Thailand, as cited in the first protologue. Ardisia alata belongs to the subgenus Pyrgus Mez of the genus Ardisia (Larsen and $\mathrm{Hu}, 1996)$. Some of the distinguishing morphological characters of $A$. alata from other members of the subgenus Pyrgus include short inflorescence $(2-5 \mathrm{~cm})$, branches bearing few florets $(1-2$ florets) and distinctly winged petiole (Larsen and $\mathrm{Hu}, 1996)$.

During a taxonomic revision of the genus Ardisia in Thailand, we studied both the protologue and the type specimens of $A$. alata kept in main herbaria (both in Europe and Thailand), we found that when H.R. Fletcher, the author, published the name A. alata as a new species, cited the specimens "Kerr 17125" (full collector name written on the herbarium sheet was A. F. G. Kerr) as the plant from Thailand in Phangnga Province (Takuapa and Kapong districts) (Fletcher, 1937), but did not designate the holotype. We found that there were four duplicates of the specimens “A.F.G. Kerr 17125" kept in BK, BM, E and K. The specimen kept in E is a syntype as a detail notes on the herbarium sheet, but there are no notes on the herbarium sheets of the remaining three specimens and all of them were regarded as syntypes [Art. 9.6 of the ICN (Turland et al., 2018)], so the name A. alata needs a lectotypification. Among the three duplicates of A.F.G. Kerr 17125, the one kept in $\mathrm{K}$ (barcode $\mathrm{K} 000756775$ ) was a perfect match to the description given in the protologue and there were both branches and flowers on the herbarium specimen, and therefore, this specimen is selected as the lectotype. The lectotypification of this name is provided as follows:

Ardisia alata H.R. Fletcher, Bull. Misc. Inform. Kew 1937(1): 26 (1937).

Lectotype (designated here): Thailand. Phangnga Province (Takuapa and Kapong districts): alt. ca. $100 \mathrm{~m}$., by stream in evergreen forest, 17 Feb. 1929, A. F. G. Kerr 17125 (K barcode K000756775 [digital photograph!]); isolectotype: BK!, BM [digital photograph!], E [digital photograph!]).

\footnotetext{
${ }^{1}$ Corresponding Author. Email: wannachaichatan@gmail.com
} 


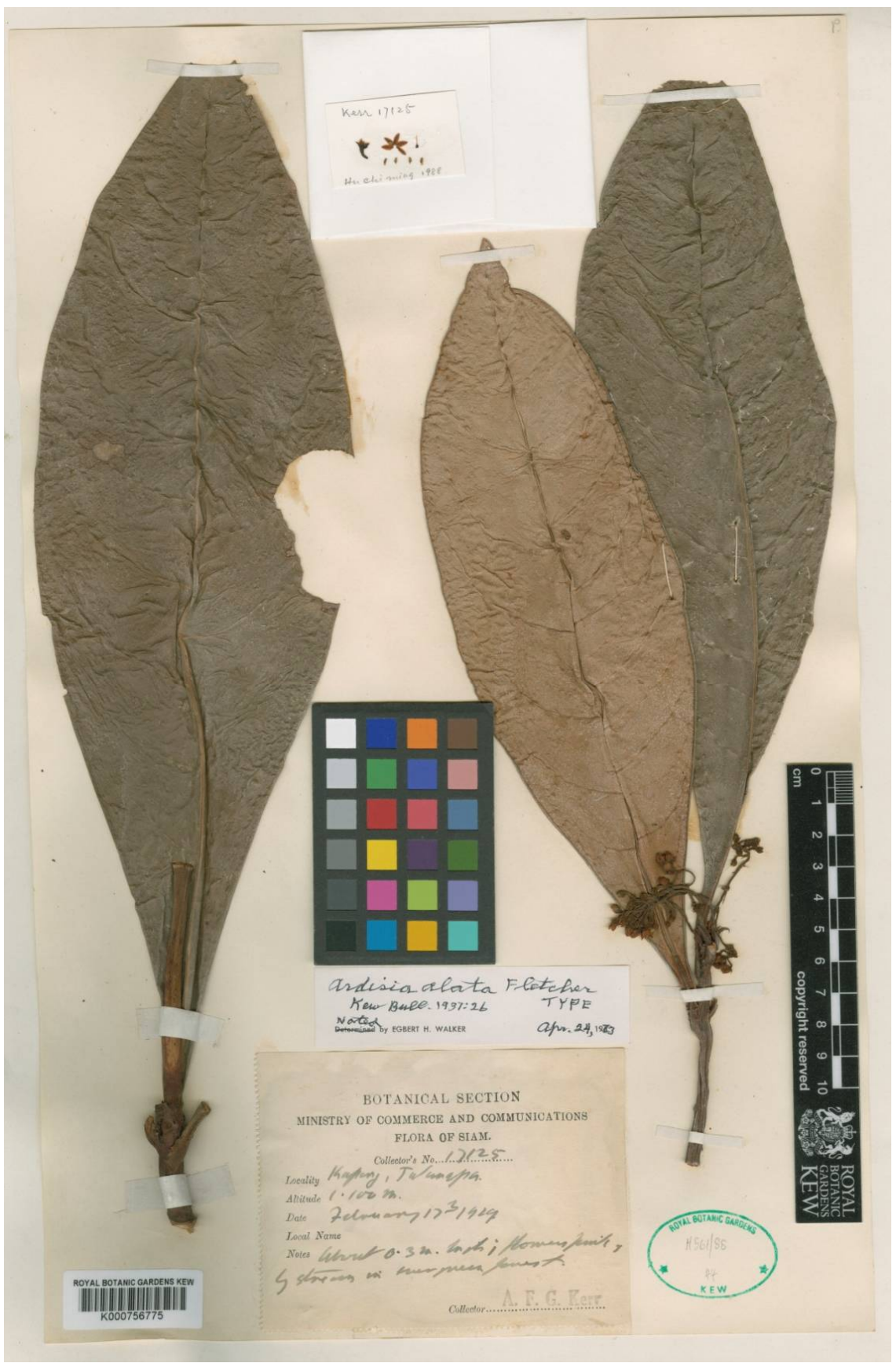

Fig. 1. Ardisia alata H.R. Fletcher [Kerr 17125 (lectotype, K barcode K000756775)]. Reproduced with permission of the Royal Botanic Gardens, Kew (K). 


\section{Acknowledgements}

The authors are indebted to the curators and officers in BK, BM, E and K for their help on providing information on the type specimens for the study. The authors are thankful to Dr. Jolyon Dodgson, Faculty of Science, Mahasarakham University for linguistic advice. This research was financially supported by Mahasarakham University.

\section{References}

Chen, J. and Pipoly, J.J. III. 1996. Myrsinaceae. In: Wu, Z.Y. and Raven, P.H. (Eds), Flora of China. Vol. 15 (Myrsinaceae through Loganiaceae). Science Press, Beijing, and Missouri Botanical Garden Press, St. Louis, pp. 1-38.

Fletcher, H.R. 1937. Contributions to the Flora of Siam, Additamentum. XLI. Bull. Misc. Inform. Kew 1937(1): 26-44.

Larsen, K. and Hu, C.-M. 1996. Myrsinaceae. In: Larsen, K. (Ed.), Flora of Thailand. Vol. 6(2). Diamond Printing, Bangkok, Thailand, pp. 81-178.

Ståhl, B. and Anderberg, A.A. 2004. Myrsinaceae In: Kubitzki, K. (Ed.), The Families and Genera of Vascular Plants 6. Springer, Berlin, pp. 266-281.

Turland, N.J., Wiersema, J.H., Barrie, F.R., Greuter, W., Hawksworth, D.L., Herendeen, P.S., Knapp, S., Kusber, W.-H., Li, D.-Z., Marhold, K., May, T.W., McNeill, 70 J., Monro, A.M., Prado, J., Price, M.J. and Smith, G.F. (Eds) 2018. International Code of Nomenclature for Algae, Fungi, and Plants (Shenzhen Code) adopted by the Nineteenth International Botanical Congress Shenzhen, China, July 2017. Regnum Vegetabile 159. Glashütten: Koeltz Botanical Books.

(Manuscript received on 12 February 2018; revised on 4 November 2018). 